\title{
Distribution of charophyte species in Estonian coastal water (NE Baltic Sea)*
}

\author{
KAIRE TORN ${ }^{1,2}$, GEORG MARTIN ${ }^{1}$, HENN KUKK $^{1,3}$ and TIIU TREI ${ }^{4}$ \\ ${ }^{1}$ Estonian Marine Institute, University of Tartu, Marja 4d, 10617 Tallinn, Estonia. E-mail: kairet@klab.enir.ee \\ ${ }^{2}$ Institute of Botany and Ecology, University of Tartu, Lai 40, 51005 Tartu, Estonia. \\ ${ }^{3}$ Tallinn Pedagogical University, Narva mnt. 25, 10120 Tallinn, Estonia. \\ ${ }^{4}$ Institute of Zoology and Botany, Estonian Agricultural University, Riia 181, 51014 Tartu, Estonia.
}

\begin{abstract}
SUMMARY: Charophytes constitute a group of macrophytes that usually inhabit soft bottoms with shallow water. They occur mostly in fresh-water environments but can also be found in brackish waters. Due to their requirement for clear water they are considered sensitive to eutrophication and therefore often used as an indicator for good water quality. The diverse structure of the Estonian coastline with its numerous sheltered bays and shallow, soft-bottom archipelago areas coupled with low salinity conditions provides an excellent habitat for charophytes. To date, seven species have been described in Estonian coastal waters, NE Baltic Sea. Last systematic investigations on charophyte distribution date back 20-30 years. During the summer of 2001 the locations where charophytes have previously been found were revisited and new sites sampled, to describe the present distribution of quantitative and qualitative parameters of charophyte species. Sampling was performed mainly by SCUBA diving; occurrence, abundance and wet weight biomass were estimated for each location. Six species of charophytes were identified. Compared to previously recorded material, no significant changes in the distribution pattern of charophytes were found. The dependence of charophyte distribution on environmental settings was tested, with depth and substrate quality explaining most of the variability in distribution. Salinity within observed range had minor influence on charophytes.
\end{abstract}

Key words: Charophytes, Baltic Sea, depth distribution, salinity.

RESUMEN: Distribución de las ESPECIES DE CARÓFITOS EN AgUAS COSTERAS DE Estonia (MAR BÁltico NE). - Los Carófitos son un grupo de macrófitos que por lo general viven en fondos blandos con aguas someras. Se encuentran sobre todo en ambientes de agua continental, pero pueden hallarse asimismo en aguas salobres. Debido a su necesidad de aguas transparentes con frecuencia se les considera sensibles a la eutrofización y, por ello, suelen ser utilizados como indicadores de buena calidad del agua. La estructura variada del litoral de Estonia, con sus numerosas bahías resguardadas y áreas de archipiélagos con fondos blandos y someros, junto a condiciones de baja salinidad, proporciona un hábitat excelente para los carófitos. Hasta la fecha se han descrito siete especies de carófitos en las aguas costeras de Estonia, en el NE del mar Báltico. Las últimas investigaciones sistemáticas sobre la distribución de los carófitos se remontan a hace 20-30 años. Durante el verano de 2001 se volvieron a visitar las localidades en las que previamente se habían encontrado carófitos y se muestrearon nuevos emplazamientos, para describir la distribución actual de parámetros cuantitativos y cualitativos relativos a las especies de carófitos. El muestreo se realizó principalmente mediante buceo con escafandra autónoma; para cada localidad se estimaron la presencia, abundancia y biomasa en peso húmedo. Se identificaron seis especies de carófitos. Comparado con el material registrado previamente, no se descubrieron cambios importantes en la pauta de distribución de los carófitos. Se comprobó la dependencia de la distribución de los carófitos de las características ambientales, y la profundidad y el sustrato explicaron la mayor parte de la variabilidad en la distribución. La salinidad, dentro del rango observado, tuvo una menor influencia en los carófitos.

Palabras clave: Carófitos, mar Báltico, distribución batimétrica, salinidad. 


\section{INTRODUCTION}

The Characeae (stoneworts, muskgrasses or bassweeds) constitute a group of macrophytes found on all continents except Antarctica. Of 314 species reported by Wood and Imahori (1965) only six were in evidence on all continents (Gollerbach and Krasavina, 1983). Charophytes occur both in fresh and brackish waters and only one species is able to tolerate high salinity levels. Considerable variability in salinity preferences exists between different charophyte species (Corillion, 1975).

Charophytes can inhabit various substrates. As they attach to the bottom by a delicate system of rhizoids most species prefer soft, muddy bottoms (Hutchinson, 1975). Many species are adapted to grow in conditions with very low light intensity. In waters with low turbidity, charophytes can penetrate to deeper areas than vascular plants (Chambers and Kalff, 1985). The differences in light conditions and wave exposure are supposed to be the main reason for the great extent of polymorphism within the species, causing enormous problems with species determination within this group of macroalgae. Shallow areas are inhabited by short, highlybranched forms while deeper waters are inhabited by plants with a prolonged thallus (Olsen, 1944; Corillion, 1975).

Charophytes are supposed to be good indicators of eutrophication (Kohler, 1975; Krause, 1981). Increasing eutrophication leads to increased phytoplankton growth, which in turn causes a deterioration of underwater light conditions and changes in the spectral composition of light. Characeae occur only in very shallow areas of such eutrophic waters (Yousef et al., 1997).

According to Nielsen et al. (1995) only 15 charophyte species have adapted to the brackish environment of the Baltic Sea, but difficulty of drawing the line between fresh and brackish environments in the Baltic Sea conditions may explain why some freshwater species of lagoons and ditches are found in the scientific literature describing the Baltic Sea region (Olsen, 1944; Hasslow, 1931; Luther, 1951; Blindow, 2000). For the coastal waters of Estonia (NE Baltic Sea) only 7 species have been reported so far: Chara aspera Dethard. ex Willd., C. baltica Bruz., C. canescens Loisel., C. connivens Salzm. ex Braun, C. tomentosa L., C. contraria Braun ex Kütz. and Tolypella nidifica Braun (Trei, 1991a; Nielsen et al., 1995).

The share of charophytes in total phytobenthic biomass for the Gulf of Riga and inner sea of West-
Estonian Archipelago has been estimated at 1-2\% (Martin, 2000). Consequently, charophytes have been thought to have a minor role in the total energy and matter flows of the coastal ecosystem in the NE Baltic Sea. However, recent data (unpublished) show that these figures are heavily underestimated. This is due to the fact that charophytes mostly occur in very shallow waters and have been usually excluded from the scope of phytobenthic investigations. The importance of charophytes is high in the Estonian coastal ecosystem compared to many other Baltic areas because of the geomorphology of the Estonian coastline, dominated by numerous shallow, soft-bottom bays.

Contemporary data about the state of charophytes in Estonian coastal waters are almost nonexistent. Most comprehensive work in this subject has been conducted many decades ago (Pork, 1954; Trei, 1977; Kukk, 1980). The aim of the present study was to give an overview of the occurrence of charophytes along the Estonian coastline and to relate their distribution to environmental settings. Alongside, long-term changes in distribution patterns as well as the quantitative parameters of charophyte communities were to be described.

\section{MATERIALS AND METHODS}

The material for the present study was collected during the spring and summer of 2001. Observation sites were chosen to represent conditions most likely to suit charophyte communities (e.g. shallow softbottom bays and lagoons) and revisit former sampling sites (Fig. 1). Sampling grid was designed to cover as much of the Estonian coastline as possible. Some areas, e. g. Matsalu Bay, Haapsalu Bay, Rame Bay and the southern coast of the Saaremaa Island, were allocated a higher frequency of observations because of the need to match with former sampling localities. Former data for comparison were obtained from the field diaries of Trei (1962-1985) and the material collected by Kukk (1980) in 1970-1978.

Altogether 94 localities along the Estonian coastline were visited and descriptions from 142 sites obtained. In some localities different depth zones were treated as different sites. Sampling was performed by SCUBA diving from the boat (39 localities) or directly from the shore (55 localities). When sampling from shore, depth range of observations was limited by technical reasons to 1-2 m, so not all possible charophyte depth range was covered. 


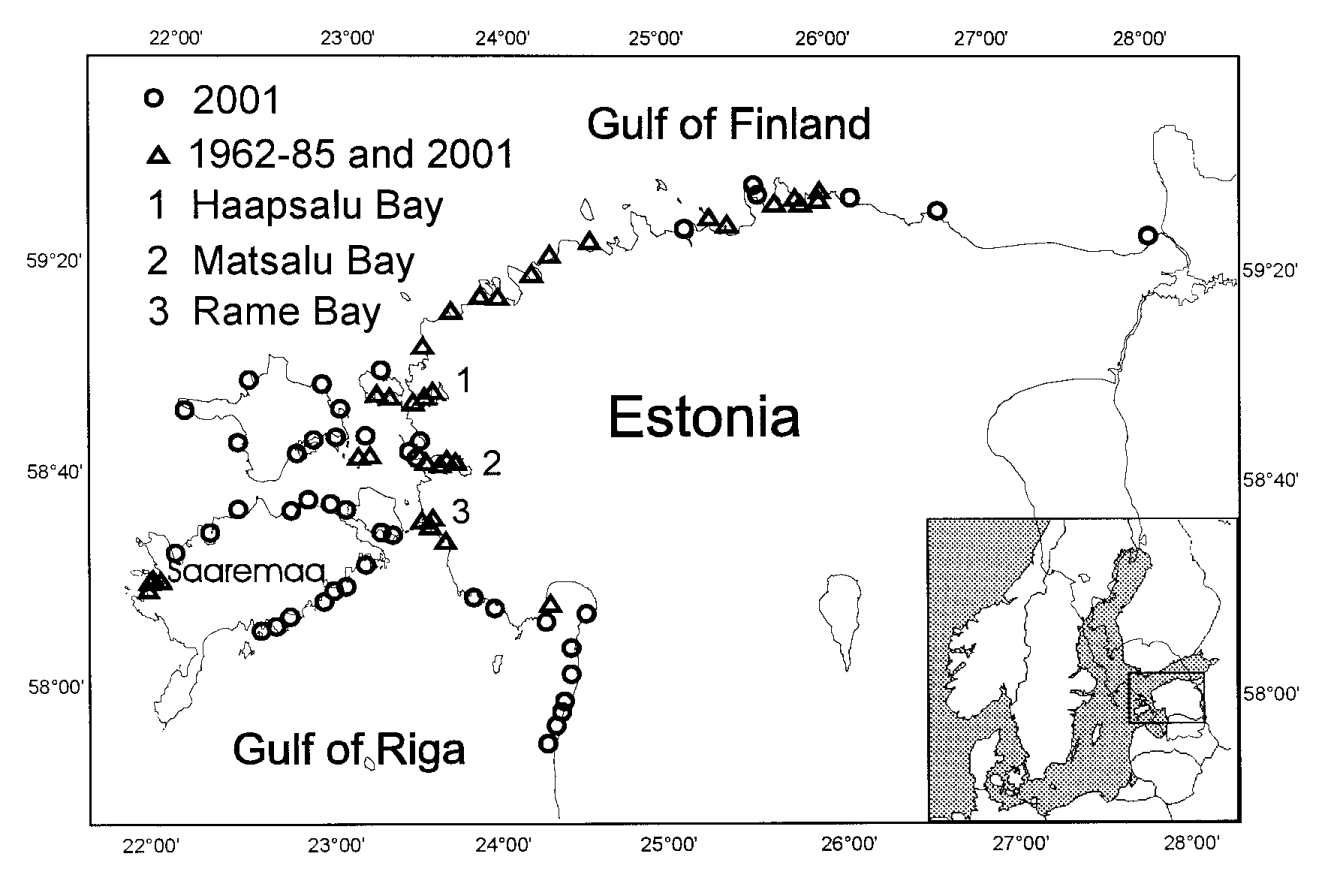

Fig. 1. Location of sampling localities in Estonian coastal waters.

For each locality, its GPS position was recorded. The biological parameters recorded were total coverage of benthic vegetation in each site and coverage of species. The environmental variables recorded were water salinity (using a $\mathrm{HACH}$ conductivity meter), depth (divers depth gauge) and bottom composition (visual description according to created classification). Quantitative samples of macrophyte communities were collected from 31 sites, taken using 20 x $20 \mathrm{~cm}$ frame placed randomly in the interested depth interval. Collected quantitative and qualitative samples were packed, labelled and then preserved frozen until sorting and determination. In the laboratory, species were determined and biomass (wet weight) of charophytes and other species was measured. Biomass is presented as wet weight $\mathrm{m}^{-2}$.

All sampling sites fell into the depth interval of 0-4.8 $\mathrm{m}$ and salinity range $0.64-6.63 \mathrm{PSU}$. For analytical reasons, the depth range was divided into intervals (Fig. 2) and the salinity of water using the example from Blindow (2000), respectively. Areas with salinity lower than 0.5 PSU were not considered in the present investigation. In most localities, the bottom consisted of sandy substrate with mud or stones. For analysis, a bottom substrate coding was devised to reflect the "soft-hard" gradient (Table 1; see Kautsky, 1989).

The evaluation of the effect of the different environmental factors on the distribution of charophytes was performed by CCA (Canonical Correspondence
Analysis) technique (ter Braak 1986, 1994). Canonical correspondence analysis is unique among the ordination methods in that the ordination of the main matrix (by reciprocal averaging) is constrained by a multiple regression on variables included in the second matrix. In community ecology, this means that the ordination of samples and species is constrained by their relationships to environmental variables. In our case the environmental variables tested were salinity, depth and bottom composition. The latter was considered to reflect several environmental factors, such as wave activity, possible differences in nutrients regime, etc.

\section{RESULTS}

Out of 94 investigated locations charophyte species were present in 77 . During the investigations, 6 species of charophytes were found. The most frequent of them was C. aspera (found in $55 \%$ of all sites; Fig. 3). C. baltica, C. canescens and T. nidifica were found in about $20 \%$ of the study sites. T. nidifica was found all over the Estonian coastline, while $C$. baltica, $C$. connivens (both male and female specimens) and $C$. tomentosa were restricted to Western Estonia and not found in the Gulf of Finland. In one single case the determination problem occurred with specimens of $C$. baltica which could be determined as $C$. contraria according to different 

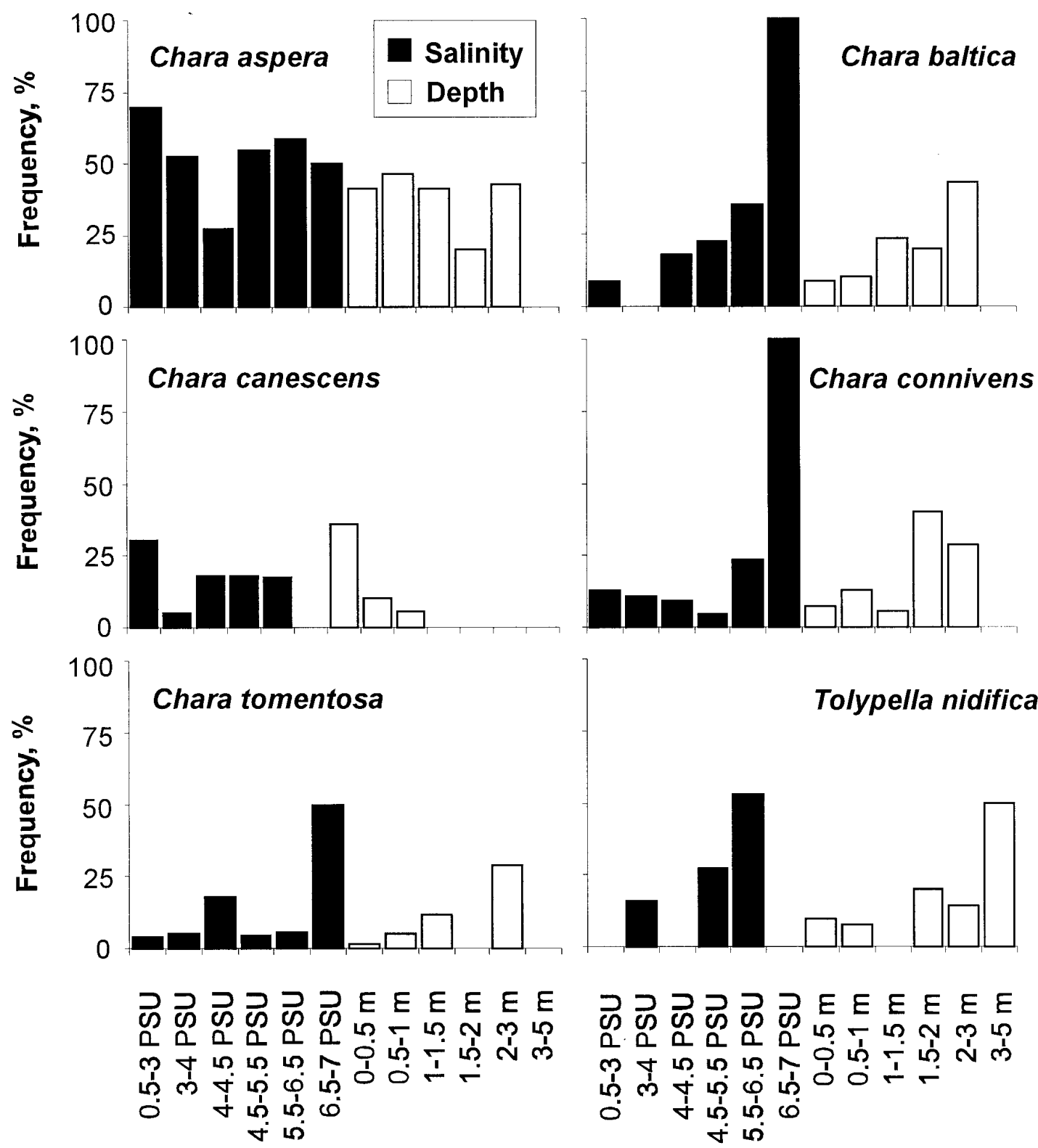

Fig. 2. Frequency of charophyte species findings in different salinity and depth intervals in Estonian coastal waters. Frequency is calculated as occurrence of species in locations with certain salinity or depth interval.

TABLE 1. - Bottom substrate coding (according to Kautsky, 1989).

$\begin{array}{lllll}\begin{array}{l}\text { mud } \\ \text { mud } \\ \text { clay }\end{array} & \begin{array}{l}\text { sand } \\ \text { sand }\end{array} & & & \\ \text { mud } & \begin{array}{l}\text { sand } \\ \text { sand } \\ \text { sand }\end{array} & & \begin{array}{l}\text { stones+ } \\ \text { stones+ }\end{array} & \begin{array}{l}\text { boulders+ } \\ \text { boulders+ }\end{array} \\ \text { mud } & \text { sand } & \text { gravel } & \text { stones } & \\ & \text { sand } & \text { gravel } & \text { stones } & \\ & \text { sand } & & \begin{array}{l}\text { stones } \\ \text { stones } \\ \text { stones }\end{array} & \text { boulders } \\ & & & \text { boulders } \\ & & & \text { boulders }\end{array}$

- rare occurrence keys (Gollerbach and Krasavina, 1983; Blindow and Krause, 1990).

From 94 observed localities, 44 had former records of the presence of charophytes. Two species, $C$. baltica and C. connivens, were not recorded previously from the localities visited in 2001 while the former records exist from other localities in Estonian coastal water (Fig. 4.). C. contraria was not definitely determined during the 2001 observations, while in previous material it had been present in one locality in Matsalu Bay (Trei, 1991a, 1991b). In $11 \%$ of the cases (5 from 44), charophytes had disappeared from the localities where they were recorded previously. 


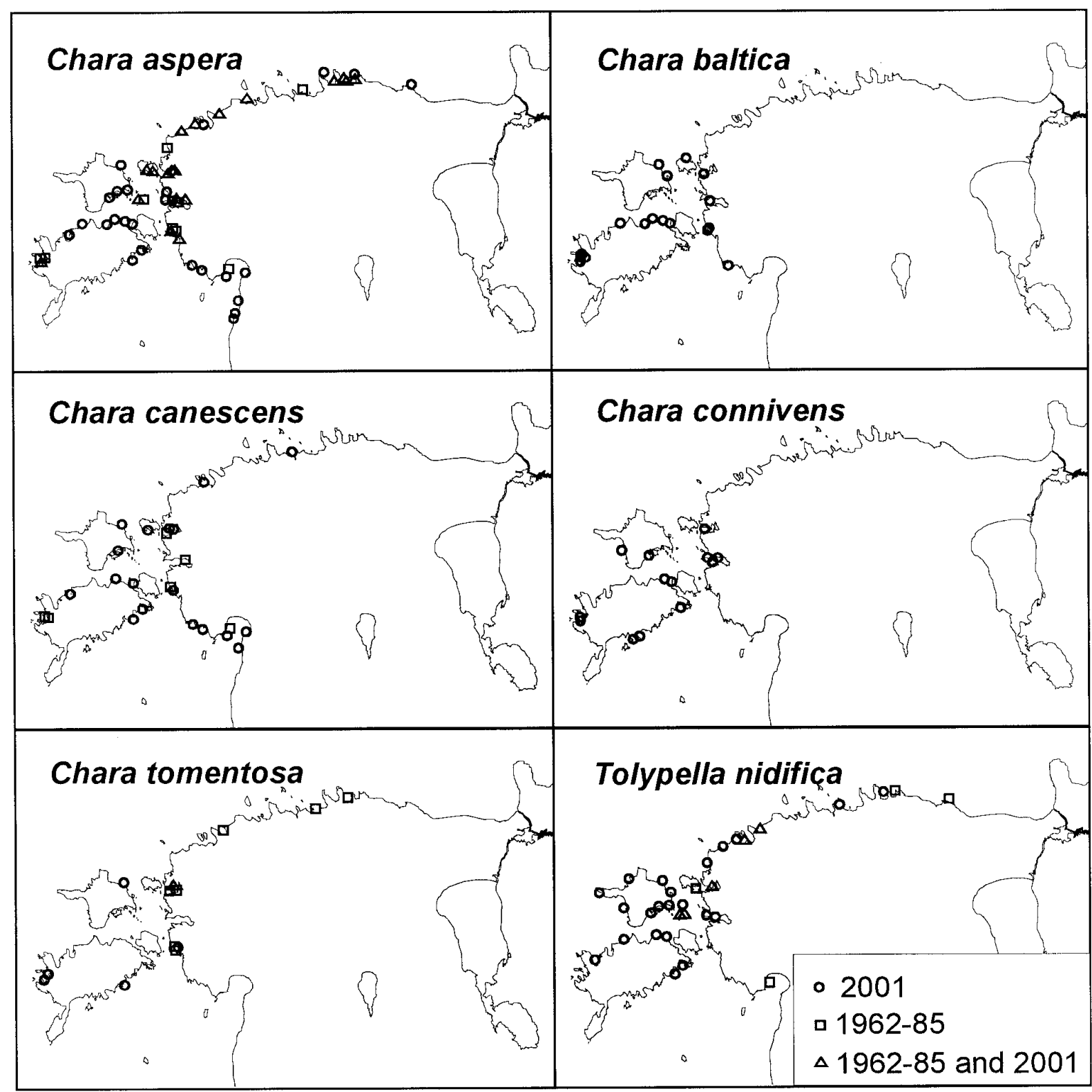

Fig. 3. Former and recent findings of charophyte species in Estonian coastal waters. Only revisited former locations are presented.

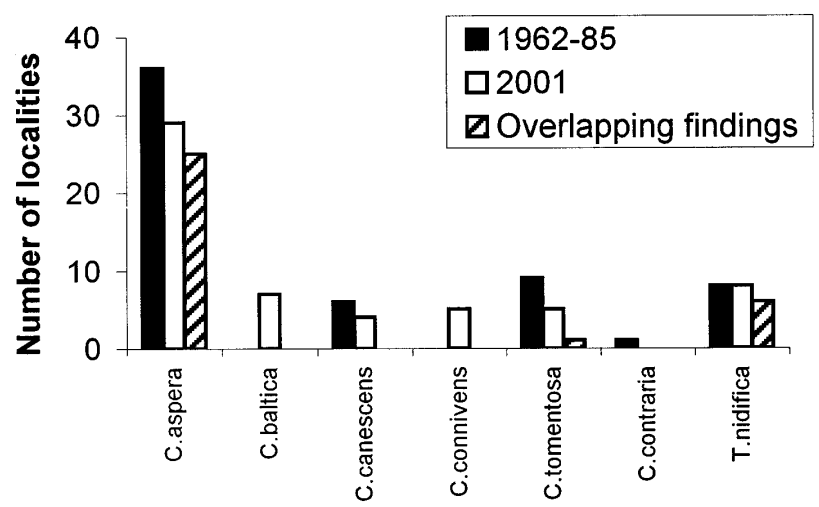

Fig. 4. Number of charophyte records among revisited locations in Estonian coastal waters.
Different environmental variables were only weakly correlated with each other in CCA analyses (CCA, $\left.\mathrm{r}_{\text {depth/bottom }}=0.31 ; \mathrm{r}_{\text {depth/salinity }}=0.13 ; \mathrm{r}_{\text {salinity/bottom }}=0.08\right)$.

The highest correlation with ordination axes was obtained in the environmental variable "depth" (Fig. 5). Even such a small depth range as $0-4.8 \mathrm{~m}$ had a major influence on the quantitative (coverage) and qualitative (species) parameters of charophytes. Different species had different depth preferences. $T$. nidifica was present in the whole depth interval, but preferred greater depth. $C$. canescens was present down to $1.1 \mathrm{~m}$. C. aspera was equally found in all depth intervals. The remaining species preferred the depth interval $1.5-3 \mathrm{~m}$. 


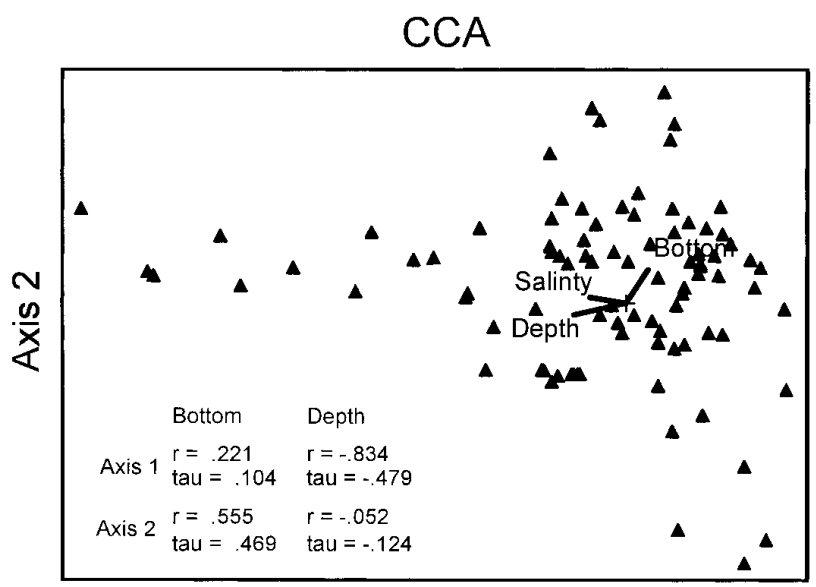

Axis 1

Fig. 5. Result of CCA ordination of charophyte community data (r, Pearson's correlation coefficient; tau, Kendall's correlation coefficient).

Axis 2 of the CCA ordination was highly correlated with the variable "bottom" (Fig. 5). As the analysis was performed on the communities containing charophyte species (and thus having at least a fraction of soft substrate) it showed that the ratio of the coverage of soft bottom to hard bottom was an important parameter in describing the variability in appearance of charophyte species.

Salinity in the observed range had also some structuring influence on the quantitative parameters of charophyte communities, but ranked below depth and bottom composition. C. baltica, C. connivens and $C$. tomentosa preferred salinities higher than 5.5 PSU (Fig. 2). T. nidifica demonstrated a similar trend in salinity preference. $C$. aspera and $C$. canescens seemed to have no salinity preference within the observed range.

In almost all sites where the charophytes were recorded, the total coverage of phytobenthic communities was $100 \%$. In half of the cases with a presence of $C$. aspera and $C$. tomentosa, these species were dominating phytobenthic communities. Very often charophytes were covered by a carpet of Cladophora glomerata and other filamentous species. In some cases, $C$. tomentosa was growing together with other charophyte species. $C$. aspera and $C$. tomentosa had the highest biomasses among charophytes (5-998 $\mathrm{g} \mathrm{m}^{-2}$ and 981$1478 \mathrm{~g} \mathrm{~m}^{-2}$ respectively). C. canescens was present usually in single specimens within $C$. aspera populations; only in one location did $C$. canescens predominate over $C$. aspera. $C$. canescens was frequently found together with filamentous green algae.
C. baltica, C. connivens and T. nidifica preferred communities where aquatic vascular plants were dominant (Potamogeton pectinatus, Ruppia maritima, Zannichellia palustris). C. baltica was usually present with coverage values reaching $20-50 \%$ or as single specimens. Most frequently it was found together with $C$. aspera, but in these cases $C$. baltica was not dominant. Compared to C. aspera, $C$. baltica had fewer epiphytes. C. connivens was most often covered less than 5\%. T. nidifica was most frequently found in communities dominated by vascular plants, but also together with $C$. aspera.

\section{DISCUSSION}

Members of two charophyte genera, Tolypella and Chara, are present in Estonian coastal waters. Chara aspera, the most frequent species in our material, is described in the literature as a widespread species common all over the Baltic Sea, often forming monodominant communities (Pork, 1954; Trei, 1991a). In our material, C. baltica was found only as single specimens, while in other areas of the Baltic Sea this species is forming monodominant stands (Künzenbach, 1955-56; Kornas, 1959). C. connivens is considered to be very rare in the Baltic (Luther, 1979; Trei, 1991a; Blindow, 2000). In our material it was found in several locations, mostly as single specimens growing together with phanerogamic species. C. tomentosa was supposed to be a common species for Estonian coastal waters (Trei, 1991a); we failed to find this species in its former locations in the Gulf of Finland (Kukk, 1980) but recorded it several times in the West-Estonian Archipelago. Tolypella nidifica has been previously described as a rare species (Lippmaa, 1936; Pork, 1954), but we found this species all over the study area in all depth intervals. C. contraria has been considered to be rare also in the former literature and there have not been any records of findings since the 1970s (Trei, 1991a, 1991b). Doubtful determination of a single $C$. contraria specimen in our material does not allow drawing larger conclusions about long-term dynamics of this species in the investigated sea area.

The differences in distribution pattern of charophyte species between present material and former data turned out to be minor. Serious changes have been reported for other algal groups in the area, e. $\mathrm{g}$. the decline of Fucus vesiculosus population in the northern Gulf of Riga (Martin, 2000). Some decline 
in the occurrence of $C$. aspera and $C$. tomentosa could be observed, yet at the same time $C$. baltica and $C$. connivens had spread their distribution. No significant difference was observed also in the biomass distribution of the most common charophyte species. We measured the maximum wet weight for $C$. tomentosa at $1.5 \mathrm{~kg} \mathrm{~m}^{-2}$. In former data, the maximum biomass had been measured at $2.7 \mathrm{~kg} \mathrm{~m}^{-2}$ (by Trei in 1983 in Rame Bay). These values are still not very high because, according to the literature, the biomass of $C$. tomentosa communities can reach $14 \mathrm{~kg} \mathrm{~m}^{-2}$ in favourable, sheltered conditions (Lindner, 1978).

Depth influences benthic macrophytes indirectly, mainly as a function of light intensity and wave exposure. Corillion (1975) has divided charophyte species into three groups according to their depth preferences: 1) species growing mostly in areas shallower than $1 \mathrm{~m}(C$. canescens $) ; 2)$ species growing to the depth of $2 \mathrm{~m}(C$. connivens $) ; 3)$ species growing to the depth of $5 \mathrm{~m}(C$. aspera, $C$. baltica). Species belonging to the first group have their productivity directly connected to the light quality, while species belonging to the third group are not so light-dependent (Olsen, 1944; Corillion, 1975). According to Trei (1991), T. nidifica can penetrate to the depth of 6-7 $\mathrm{m}$ in Estonian waters, according to Olsen (1944) T. nidifica has a depth range up to $8 \mathrm{~m}$, and according to Lakowitz (1929) its depth limit is $15 \mathrm{~m}$. Our data show a high dependence of charophyte community structure (both quantitative and qualitative) on habitat depth. Considering individual species, our data in most cases confirm these literature findings.

Salinity is one of the major factors limiting the geographical distribution of charophyte species in the Baltic Sea. C. aspera has the widest salinity range in our study as well as in former publications (Trei, 1983, 1991; Blindow, 2000). In our material this species was found in fresh-water areas as well as in areas with salinity up to 7 PSU. According to Blindow (2000), C. baltica and T. nidifica can be found in a wide salinity range but prefer higher salinity values. The minimum salinity for $C$. canescens is reported to be 3.3 PSU (Luther, 1951). In our material, $C$. canescens was mostly found at salinities less than 3 PSU. This species has not been recorded at such low salinity in other parts of the Baltic (Blindow, 2000). Corillion (1975) suggests the optimum salinity for it to be 5 PSU. C. connivens is found near the Swedish coast in a salinity range of 5.5-6.5 PSU (Blindow, 2000). We found this species at lower salinity values (2.5-6.6 PSU). According to our data (also confirmed in the literature), T. nidifica prefers salinities higher than 5 PSU (Trei, 1991a; Blindow, 2000).

There exist little data about the substrate preference of charophyte species. It is generally presumed that charophytes inhabit soft, sandy or muddy bottoms. However, our data show that charophyte communities are sensitive also to differences in substrate quality within soft substrates. C. baltica is known to be able to grow on extremely hard substrates such as limestone rock, attaching to small irregularities in rock surface (Trei, 1991a). C. aspera is also commonly supposed to inhabit soft, muddy substrates but can be found on bottoms covered by stones of different size. In our study, C. aspera inhabited bottoms of different quality while its coverage and biomass were dependent on the proportion of soft and hard substrate.

Though studies on the effect of eutrophication on charophytes are not so common in brackish water (e.g. Yousef et al., 1997), they indicate that these plants are sensitive to eutrophication and are useful bioindicators also in this type of water (Blindow, 2000). Charophyte ecology is much better studied in fresh than in brackish water. Many studies show a decline of charophytes during eutrophication (e.g. Blindow, 1992, van den Berg et al., 1999), and charophytes have thus been used as bio-indicators for high water quality (Kohler, 1975; Krause, 1981). As a result, today only 2 species (Chara globularis and Chara vulgaris) of all Characeae species in Germany are not endangered, while the rest are either endangered or near extinction, or have already disappeared (Yousef et al., 1997). From species found during the present study, in Sweden, T. nidifica and $C$. connivens are listed as threatened, $C$. canescens and $C$. baltica as vulnerable, $C$. tomentosa as requiring protection, with only $C$. aspera regarded as beyond danger (Blindow, 1994). Our data show that charophytes were not significantly affected by differences of the nutrient levels between separate sea areas: in the Gulf of Riga, where natural nitrogen concentrations exceed 2-3 fold the concentrations of Baltic proper and where primary production level is twice that in other parts of the Baltic Sea (Yurkovskis et al., 1993; Suursaar, 1995; Mägi and Lips, 1998). Consequently, eutrophication level per se is not the primary factor determining the distribution of charophytes in the sea area described. More empirical studies are needed to demonstrate the role of environmental factors on the charophyte distribution. 


\section{CONCLUSIONS}

Following the previous discussion, the following conclusions can be drawn: (i) C. connivens is not rare in Estonian coastal waters; at least, no more than was reported previously; (ii) there have not been any large-scale changes in charophyte distribution patterns in Estonian coastal waters during recent decades, in contrast with the big changes in other macroalgal groups; and (iii) depth and substrate exert most of the influence on the distribution patterns of charophytes in Estonian coastal waters, while salinity seems not to have such a strong effect.

\section{ACKNOWLEDGEMENTS}

The present study was conducted under the framework of Estonian governmental programme no. 0200792s98. The authors wish to thank Dr. Jonne Kotta and Mrs. Tiina Paalme for valuable comments on the manuscript. We are also grateful to Dr. Marja Koistinen for help with charophyte determination and Mr. Jaak Timpson for technical assistance during fieldwork.

\section{REFERENCES}

Blindow, I. - 1991. Reasons for the decline of Charophytes in eutrophicated lakes in Scania (Sweden). Extant and Fossil Charophytes. Bull. Soc. Bot. Fr., 138: 95.

Blindow, I. - 1992. Decline of charophytes during eutrophication: Comparison with angiosperms. Freshwat. Biol., 28: 9-14.

Blindow, I. - 1994. Rare and threatened charophytes in Sweden. Sven. Bot. Tidskr., 88: 65-73.

Blindow, I. - 2000. Distribution of Charophytes along the Swedish Coast in Relation to Salinity and Eutrophication. Internat. Rev. Hydrobiol., 85: 707-717.

Blindow, I. and W. Krause. - 1990. Bestämningsnyckel för svenska kransalger. Svensk Botanisk Tidskrift, 84: 119-160.

Chambers, P. A. and J. Kalff. - 1985. Depth distribution and biomass of submersed aquatic macrophyte communities in relation to Secchi depth. Can. J. Fish. Aquat. Sci., 42: 701-709.

Corillion, R. - 1975. Flore des Charophytes (Characées) du Massif Armoricain et des Cointrées voisines d'Europe occidentale, 4. Paris.

Gollerbach, M. M. and L. K. Krasavina. - 1983. Opredelitel presnovodnyh vodoroslei SSSR. 14. Harovye vodorosli. Nauka: 190. [Determination key of fresh-water algae of the USSR. 14. Charophytes., in Russian].

Hasslow, O.J. - 1931. Sveriges characéer. Bot. Not., 3: 63-136.

Hutchinson, G.E. - 1975. A Treatise on Limnology, 3. Wiley, New York.

Kautsky, H. - 1989. Quantitative Distribution of Plant and Animal
Communities of the Phytobenthic Zone in the Baltic Sea.Askö laboratory, Stockholm.

Kohler, A. - 1975. Submerse Makrophyten und ihre Gesellschaften als Indikatoren der Gewässerbelastung. Beitr. naturk. Forsch. Südw.-Dtl., 34: 149-159.

Kornas, J. - 1959. Sea Bottom Vegetation of the Bay of Gdansk off Rewa. Bull. Acad. Polon. Sciences, II, 7.

Krause, W. - 1981. Characeen als Bioindikatoren für den Gewässerzustand. Limnologica, 13: 399-418.

Kukk, H. A. - 1980. Donnaja rastitelnost Finskovo zaliva u beregov SSR. Avtoref. kand. dissert. Tartu: 1-16. [Benthic vegetation of the USSR coast of the Gulf of Finland., in Russian].

Künzenbach, R. - 1955-56. Über die Algenvegetation der Ostsee und der Boddengewässern um Hiddensee. Wissensch. Zeitschr. der Ernst Moritz Arndt-Universität Greifswald. Math-nat. 5.

Lakowitz, K. 1929. Die Algenflora des gesamten Ostsee. R. Friedländer \& Sohn, Danzig.

Lindner, A. - 1978. Soziologisch-ökologische Untersuchungen an der submersen Vegetation in der Boddenkette südlich des Darss und des Zingst (südliche Ostsee). Limnologica, 11: 229-305.

Lippmaa, T. - 1936. Mereheinast ja teistest Eesti rannikuvete taimedest. Eesti Loodus, 5.

Luther, H. - 1951. Verbreitung und Ökologie der höheren Wasserpflanzen im Brackwasser der Ekenäs-Gegend in Südfinnland, II. Specieller Teil. Acta Bot. Fenn., 50.

Martin, G. - 2000. Phytobenthic communities of the Gulf of Riga and the inner sea of the West-Estonian Archipelago. Diss. Biol. Univ. Tartuensis, 64: 1-140.

Mägi, L. and U. Lips. - 1998. Budget components of water, salt and nutrients in the Gulf of Riga in 1993-95. Proc. Estonian Acad. Sci. Biol. Ecol., 47: 14-31.

Nielsen, R., A. Kristiansen, L. Mathiesen and H. Mathiesen. - 1995 Distributional index of the benthic macroalgae of the Baltic Sea area. Acta Bot. Fenn., 155: 1-51.

Olsen, S. - 1944. Danish Charophyta, Chorological, Ecological, and Biological Investigations. Kobenhavn.

Pork, M. - 1954. Eesti mändvetiktaimed (Charophyta). LUS. Abiks loodusvaatlejale, 16 .

Suursaar, Ü. - 1995. Nutrients in the Gulf of Riga. In: E. Ojaveer (ed.), Ecosystem of the Gulf of Riga between 1920 and 1990, 5: 41-50. Academia.

Ter Braak, C.J.F. - 1986. Canonical correspondence analysis: a new eigenvector technique for multivariate direct gradient analysis. Ecology, 67: 1167-1179.

Ter Braak, C.J.F. - 1994. Canonical community ordination. Part I: Basic theory and linear methods. Ecoscience, 1: 127-140.

Trei, T. Ya. - 1977. Chlorophyta and Charophyta from the coastal waters of west Estonia. Proceedings of All-Union Research Institute of Marine Fisheries and Oceanography (VNIRO),124: 27-30.

Trei, T. - 1983. Mändvetiktaimed meres. Eesti Loodus, 26: 521-526.

Trei, T. - 1991a. Taimed Läänemere põhjal. Valgus, Tallinn.

Trei, T. - 1991b. Matsalu lahe põhjataimestik. Matsalu Riiklik Looduskaitsela, Tallinn.

Van den Berg, M.S., M. Scheffer, E. Van Nes and H. Coops. 1999. Dynamics and stability of Chara sp. and Potamogeton pectinatus in a shallow lake changing in eutrophication level. Hydrobiologia, 408/409: 335-342.

Wood, R.D. and K. Imahori. - 1965. A revision of the Characeae. Cramer,Weinheim, New York.

Yousef, M.A.M., H. Nordheim, A. Kuester and H. Schubert. 1997. Characeae as bioindicators of the water quality of shallow waters at the Baltic Sea coast. Aktuelle Probleme der Meeresumwelt. Vortraege des 7. Wissenschaftlichen Symposiums 27. und 28. Mai 1997 in Hamburg 7: 173-182.

Yurkovskis, A., F. Wulff, L. Rahm, A. Andrushaitis and M. Rodriguez-Medina. - 1993. A nutrient budget of the Gulf of Riga, Baltic Sea. Estuar. Coast. Shelf Sci., 37: 113-127. 